\title{
Orchid bees (Hymenoptera, Apidae, Euglossini) are seasonal in Seasonal Semideciduous Forest fragments, southern Brazil
}

\author{
Cleiton Margatto ${ }^{1,5}$; Vinicius Ortega Berno ${ }^{1,2}$; Rodrigo Barbosa Gonçalves ${ }^{3}$ \& Luiz Roberto Ribeiro Faria ${ }^{4}$ \\ 1 Universidade Federal do Paraná (UFPR), Departamento de Biodiversidade (DBD). Palotina, PR, Brasil. \\ 2 Eastern New Mexico University (ENMU). Portales, NM, USA. ORCID: http://orcid.org/0000-0002-2491-3926. E-mail: viniciusberno@gmail.com \\ ${ }^{3}$ Universidade Federal do Paraná (UFPR), Departamento de Zoologia (DZO0). Curitiba, PR, Brasil. \\ ORCID: http://orcid.org/0000-0001-5623-0938. E-mail: goncalvesrb@gmail.com \\ 4 Universidade Federal da Integração Latino-Americana (UNILA), Instituto Latino-Americano de Ciências da Vida e da Natureza (ILACVN). Foz do \\ Iguaçu, PR, Brasil. ORCID: http://orcid.org/0000-0002-7214-106X. E-mail: nunofariajr@gmail.com \\ ${ }^{5}$ ORCID: http://orcid.org/0000-0002-9910-3127. E-mail: cleiton.margatto@gmail.com
}

\begin{abstract}
Seasonal fluctuations in the abundance of orchid bees have already been reported. The variations in population dynamics may be expected to occur in more predictable and pronounced manners in environments with a clear distinction between rainy and dry seasons, where climatic variables are regarded to be good predictors of populational patterns. The main goal of this paper is to investigate the seasonality of males of orchid bees in fragments of Seasonal Semideciduous Forest in southern Brazil. Data comprise bait samples from five one-year periods on four forest fragments. The seasonality of species abundance was tested with circular statistics. Results suggest two phenological patterns, one for Eufriesea violacea (Blanchard), Eulaema nigrita Lepeletier and Euglossa cordata (Linnaeus), whose abundances are concentrated in late spring and early-middle summer and another for Euglossa fimbriata Moure with a tendency to be collected in middle-late summer and early autumn. These patterns are discussed, as well the possible driven factors, (i) the species life cycle and nesting behavior, (ii) synchrony with resource, and (iii) climate. We can postulate an important impact of climate change in local euglossine assemblage due to the small populations and marked seasonality.
\end{abstract}

Key-Words. Annual cycles; Insect; Life-cycle; Neotropical; Seasonality.

\section{INTRODUCTION}

Phenology studies periodic life-cycle events over periods of time (Visser et al., 2010). Seasonal changes in the abundance of most tropical species are by far recognized as a main pattern in insect ecology (e.g., Wolda, 1978, 1980). Insect life history events are expected to be keyed to appropriate seasonal cycles in order to maintain ecological and biological viability of populations (Powell \& Logan, 2005). Understanding seasonal contextualized adaptations requires a broad view of the effects of temporal, spatial, and resource patterns on their dynamics (Danks, 2007). Manifold factors drive seasonal population dynamics, both abiotic (e.g., temperature and pluviosity) and biotic (e.g., resource availability, predation, and parasitism) (Riedel et al., 2008; Tauber et al., 1986; Richards \& Windsor, 2007; Turchin et al., 1999). Patterns of insect seasonality may vary for different species and habitats (Riedel et al., 2008), and can be perceived in distinct insect taxa, from species (e.g., Marinoni
\& Ganho, 2003; Sobral-Souza et al., 2015) to orders (e.g., Riedel et al., 2008).

Orchid bees (Euglossini) are rather known for their males which collect aromatic compounds from different plant families (mainly Orchidaceae) and store these compounds in their highly modified hind tibia for further attracting females (Roubik \& Hanson, 2004). There are about 230 species of orchid bees, distributed among five monophyletic genera (Moure et al., 2007; Ramírez et al., 2010). This group occurs from southern United States to northern Argentina, but most of its diversity is concentrated in Neotropical forests (Dressler, 1982; Roubik \& Hanson, 2004). Much of the existing knowledge on these bees, especially that generated by structured inventories, was enhanced by the discovery and use of synthetic chemical compounds to attract adult males (Dodson et al., 1969). This remarkable collection method was soon realized as a relevant tool for testing several ecological hypotheses (Nemésio \& Silveira, 2006). 
Seasonal fluctuations in the abundance of orchid bees have already been reported (e.g., Ackerman, 1983; Rocha-Filho \& Garófalo, 2014; Knoll, 2016), with higher abundances associated to wet (Sofia et al., 2004; RochaFilho \& Garófalo, 2014), early dry (Ackerman, 1983) and even dry season (Aguiar \& Gaglianone, 2008). Seasonality is expected to occur even in low latitude forests, where fluctuation in bee abundance seems to be slightly more intense at deciduous forests than at rainforests (Janzen et al., 1982).

On the other hand, seasonal variations in other assemblages' parameters seem not to be so clear, since species composition, evenness and dominance ranks were virtually non-seasonal (Ackerman, 1983, but see Mateus et al., 2015 for a different perspective). Among the orchid bees, Eufriesea Cockerell is known to be seasonal, and many species are found only during the rainy season (e.g., Roubik \& Hanson, 2004). Diapause is regarded to occur in the prepupal stage, and in at least some species there is only one generation per year (Kimsey, 1982). As an example, Eufriesea violacea (Blanchard, 1840), a common element of local faunas inhabiting Seasonal Semideciduous forests (e.g., Sofia et al., 2004), is only collected during late spring and summer (Peruquetti \& Campos, 1997; Sofia \& Suzuki, 2004; Gonçalves et al., 2014a, b; Sydney \& Gonçalves, 2015). However, such a strong pattern is not expected to occur for species of the other genera (e.g., Kimsey, 1982).

Among all the abiotic or biotic mechanisms that underlie seasonal patterns in abundance of insects, temporal structuring of plant resources seems to be of paramount importance for orchid bees. Besides pollen and nectar to females, plants provide most of the aromatic compounds gathered by males (Dressler, 1982; Roubik \& Hanson, 2004). In Seasonal Semideciduous Forests (SSF) sensu Veloso et al. (1991) a marked temperature variation occurs along the year, especially in latitudes above $24^{\circ} \mathrm{S}$ (Veloso et al., 1991), and significant seasonal patterns in plant phenology at SSF are linked to variables as mean temperature, pluviosity, and day length (Mikich \& Silva, 2001; Marques et al., 2004; Marchioretto et al., 2007).

Seasonal patterns in plant phenology may affect euglossine bees via the turnover of the aromatic substances provided by the plants (Abrahamczyk et al., 2012). The ability of euglossine bees to explore different scents between seasons could also be understood as an adaptation of some species to inhabit strongly seasonal habitats (Abrahamczyk et al., 2012). Euglossa mandibularis Friese, 1899 illustrates this scenario. Observations carried out in the region of Viçosa (Minas Gerais state, Brazil) by Soares et al. (1989) and Peruquetti et al. (1999) suggest this species is active only during the rainy season, when Solanum latiflorum Bohs (treated by the authors as Cyphomandra calycina Sendtn) is blooming.

Variations in population dynamics may be expected to occur in more predictable and pronounced manners in environments with a clear distinction between rainy and dry seasons, where climatic variables are regarded to be good predictors of populational patterns (see Wolda, 1988). And, in this context, studying the dynamics of eu- glossine populations in Semideciduous Seasonal Forests has an increased importance.

The main goal of this paper is to investigate the seasonality of males of orchid bees in fragments of Seasonal Semideciduous Forest in southern Brazil, answering the following question: is there any seasonal pattern in the abundance of euglossine species inhabiting these fragments?

\section{MATERIAL AND METHODS}

\section{Sampling sites}

Fieldwork was carried out in four fragments of Seasonal Semideciduous Forest in the region of Palotina, western Paraná state, southern Brazil. The region was originally covered by this forest formation, characteristic of inland areas of the Brazilian Atlantic forest biome. Nowadays the original forest was almost entirely replaced by crops, just as occurred in most of southern Brazil (Gonçalves et al., 2014a). The size of the four fragments ranges between 4.65 and 484 ha and detailed information on the location, size, sampling year, and number of scent traps (see below) employed at each site are presented in Table 1. Sites A-C are fragments in a soybean and corn crop matrix, while site $D$ is a fragment inside the urban area of Palotina, a small city with 31,564 inhabitants (IBGE, 2018). Detailed information regarding sites A and B are presented in Gonçalves et al. (2014b) and Gonçalves et al. (2014a), respectively.

\section{Sampling protocol}

Data comprise five one-year periods. Sites A and B were previously sampled (Gonçalves et al., 2014a, b) and the other two sites, $C$ and $D$, were sampled for the first time. Sites A, B and C were assessed for only one year, while site $D$ was sampled during two consecutive years (D1 and D2) (Table 1).

Euglossine sampling was carried out using baited traps (e.g., Campos et al., 1989) made from commercial $500 \mathrm{ml}$ plastic bottles containing 1,8-cineole as attractant and filled with $70 \mathrm{ml}$ of ethanol $70 \%$ (in order to prevent that specimens that had entered the trap could leave). The final design of traps follows the standard model presented by Sydney \& Gonçalves (2015). Bait traps were hung from plant branches at the edge of the fragment, about $10 \mathrm{~m}$ from each other and about $1.5 \mathrm{~m}$ above the ground. Samplings were carried out from 9 a.m. to 5 p.m. in all sites. Bees attracted to those lures were mounted in entomological pins and identified with taxonomic keys (Rebêlo \& Moure, 1996; Faria \& Melo, 2007; Nemésio, 2009) and/or by comparison with specimens previously deposited in the Coleção Entomológica Pe. Jesus Santiago Moure, Departamento de Zoologia, Universidade Federal do Paraná (DZUP). All the collected individuals are deposited in this scientific collection. 


\section{Statistical analysis}

The seasonality of species abundance was tested with circular statistics, using the software Oriana 4.2 (trial version) (Kovach, 2011). Circular analysis is often used to test hypothesis related to synchrony, periodicity, and seasonality (e.g., Zar, 1996), including several biological patterns (Batschelet, 1981). Herein, the months were treated as angles, with an interval of $30^{\circ}$ among them, so that January began at $0^{\circ}$ and December at $330^{\circ}$. At first, a mean angle corresponding to the period of greater abundance is calculated, and the intensity of the concentration of values around this mean angle (or month), represented by $R$, is measured, and could be assumed as a measure of the degree of seasonality. This vector varies from 0 , when abundance is evenly distributed along the year, to 1 , when the abundance is totally concentrated around a single period of year (see Morellato et al., 2000). So, a Rayleigh test (Z) was applied to state if the mean angle (month) can really be considered as significant (i.e., if the greater abundance is really concentrated around them). In this latter test, the null hypothesis states that when the abundance is distributed uniformly throughout the year (the distinct angles), there is no seasonality, and if the null hypothesis is rejected, the mean angle or date is significant, and the pattern is assumed as seasonal.

In order to explore the seasonality of each species in distinct spatial and temporal contexts, the analyzes were performed considering (i) the annual variation in the abundance of each species at each fragment, (ii) the variation in the abundance of each species in two years at the site $D$, and (iii) the variation in the abundance of each species considering all the sampling effort (all the fragments together, comprising four years). In all cases, only the species with an abundance greater than 30 individuals were included in each analysis.

\section{RESULTS}

\section{Newly sampled sites}

A total of 77 specimens distributed among five species and three genera were sampled in Site C (Supplementary data). The most common species was Euglossa fimbriata Moure, 1968 (39 sampled specimens), followed by Eufriesea violacea (16), Euglossa cordata (Linnaeus, 1758) (14), Eulaema nigrita Lepeletier, 1841 (six), and Euglossa pleosticta Dressler, 1982 (with only two sampled individuals).

A total of 138 specimens belonging to six species and three genera were sampled in Site D (Supplementary data). The most common species in the first year (D1) was Eg. cordata (28 sampled specimens), followed by El. nigrita (20), Eg. fimbriata (17), Euglossa annectans Dressler, 1982 (two), and Ef. violacea (with only one sampled individual). The most common species in the second year (D2) was Eg. cordata (40 sampled specimens), followed by Eg. fimbriata (17), El. nigrita (seven), Eg. pleosticta (four), and Ef. violacea (with two sampled individuals).

\section{Seasonality in species abundance}

We found evidence for seasonal patterns in the distribution of abundance of all the species in all the analyzed contexts (Table 2). Despite these seasonal patterns,

Table 1. Orchid bee phenology in Seasonal Semideciduous Forest fragments: sampling sites and details. D1: site D, first sampling year, D2: second sampling year.

\begin{tabular}{|c|c|c|c|c|c|c|c|}
\hline Site code & Site name & Latitude & Longitude & Size & Number of Traps & Sampling year & Reference \\
\hline Site A & Parque Estadual São Camilo & $-24,313197$ & $-53,916728$ & 385 & 24 & 2011-2012 & Gonçalves et al. (2014b) \\
\hline Site B & RPPN Fazenda Assu & $-24,188197$ & $-53,968388$ & 484 & 264 & $2012-2013$ & Gonçalves et al. (2014a) \\
\hline Site C & Berno Private Reserves & $-24,317976$ & $-53,829908$ & 11,2 & 72 & 2014-2015 & this study \\
\hline Site D1 & UFPR, Campus Palotina & $-24,292773$ & $-53,842261$ & 4,65 & 48 & 2014-2015 & this study \\
\hline Site D2 & UFPR, Campus Palotina & $-24,292773$ & $-53,842261$ & 4,65 & 48 & 2015-2016 & this study \\
\hline
\end{tabular}

Table 2. Orchid bee phenology in Seasonal Semideciduous Forest fragments: mean vector, month, length vector (R) and Rayleight test $(Z)$ result $\left({ }^{*} p<0.05 ;{ }^{* *} p<0.01\right)$.

\begin{tabular}{|c|c|c|c|c|c|}
\hline Species & Site & Mean vector & Mean month & Length of mean vector ( $R$ ) & Rayleigh test (Z) \\
\hline \multirow[t]{3}{*}{ Eufriesea violacea } & $A$ & $319.801^{\circ}$ & November & 0.993 & $137.973^{* *}$ \\
\hline & B & $302.19^{\circ}$ & November & 0.939 & $29.993^{* *}$ \\
\hline & all & $314.38^{\circ}$ & November & 0.969 & $181.385^{* *}$ \\
\hline \multirow[t]{4}{*}{ Euglossa cordata } & B & $2.404^{\circ}$ & January & 0.277 & $2.995^{*}$ \\
\hline & D2 & $330.798^{\circ}$ & December & 0.470 & $8.844^{* *}$ \\
\hline & $\mathrm{D} 1+\mathrm{D} 2$ & $339.896^{\circ}$ & December & 0.338 & $7.556^{* *}$ \\
\hline & all & $347.67^{\circ}$ & December & 0.355 & $15.156^{* *}$ \\
\hline \multirow[t]{5}{*}{ Euglossa fimbriata } & $A$ & $27.681^{\circ}$ & January & 0.738 & $16.878^{* *}$ \\
\hline & B & $32.429^{\circ}$ & February & 0.588 & $58.731^{* *}$ \\
\hline & $C$ & $26.062^{\circ}$ & January & 0.775 & $23.416^{* *}$ \\
\hline & $\mathrm{D} 1+\mathrm{D} 2$ & $77.265^{\circ}$ & March & 0.493 & $8.225^{* *}$ \\
\hline & all & $34.242^{\circ}$ & February & 0.603 & $99.191^{* *}$ \\
\hline \multirow[t]{2}{*}{ Eulaema nigrita } & B & $317.676^{\circ}$ & November & 0.451 & $9.776^{* *}$ \\
\hline & all & $311.059^{\circ}$ & November & 0.418 & $14.34^{* *}$ \\
\hline
\end{tabular}


Euglossa cordata was collected year-round, Eulaema nigrita and Euglossa fimbriata in all months except July, while Eufriesea violacea was only recorded from October to December (Supplementary data). Results suggest two phenological patterns, one for Eufriesea violacea, Eulaema nigrita, and Euglossa cordata, whose abundances are concentrated in late spring and early-middle summer and another for Euglossa fimbriata with a tendency to be collected in middle-late summer and early autumn.

As expected, the phenology of Eufriesea violacea was very restricted and the tests for seasonality were highly significant, even with the mean vector, $R$, assuming values close to one. In all cases the values of the mean vector corresponded to the month of November (A: $319.801^{\circ}$;
B: $302.19^{\circ}$; all fragments: $314.38^{\circ}$ ) (Fig. 1: A-C). The tests for seasonality were also significant for all the other analyzed species. For Eulaema nigrita, both analyzes also show the mean vector corresponding to a single month, November (B: $317.676^{\circ}$; all sites: $311.059^{\circ}$ ) (Fig. 1: H-I). Regarding Euglossa species, the months corresponding to the mean vectors in the respective analyzes were not exactly the same. For Euglossa cordata the mean vector corresponded to January in fragment $B\left(2.404^{\circ}\right)$ and December in all the other cases (D2: $330.798^{\circ}$; D: $339.896^{\circ}$; all fragments: $347.67^{\circ}$ ) (Fig. 1: D-G). The vectors regarding Euglossa fimbriata corresponded to an interval between January and March (A: $27.681^{\circ}$, January; B: $32.429^{\circ}$, February; C: $26.062^{\circ}$, January; D: $77.265^{\circ}$, March; all sites: $34.242^{\circ}$, February) (Fig. 2).

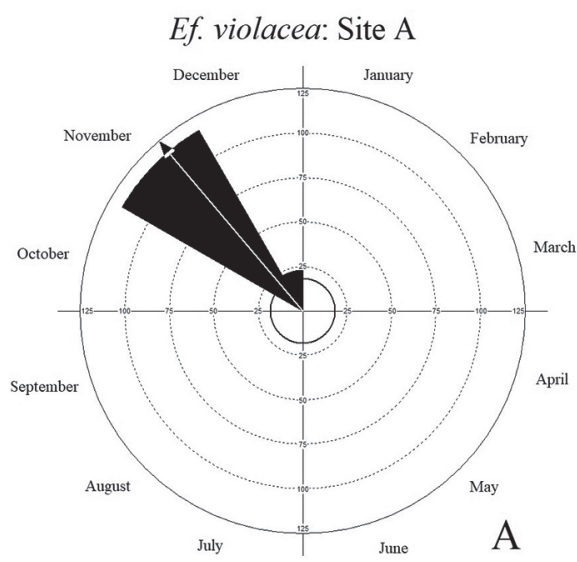

Eg. cordata: Site B

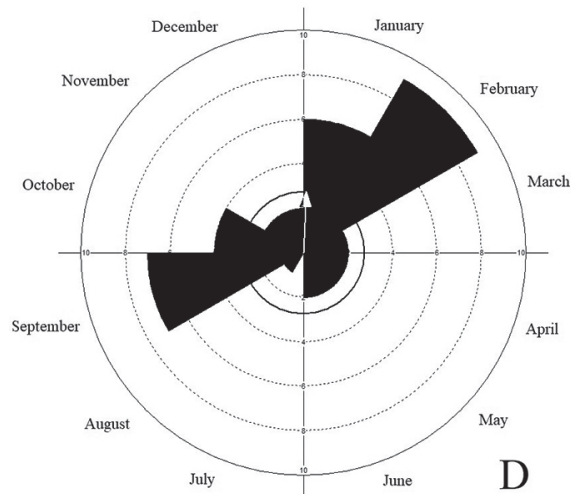

Eg. cordata: All Sites

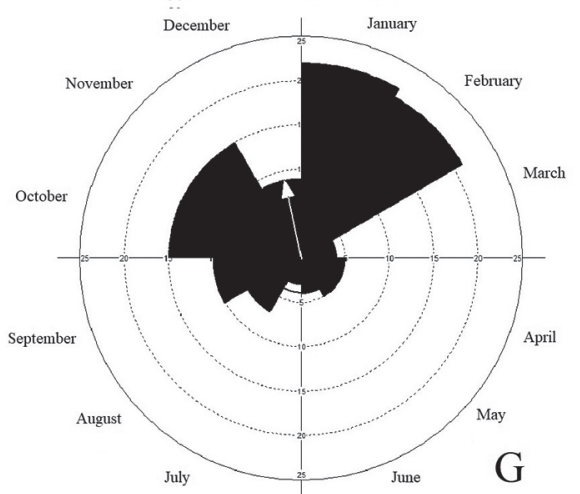

Ef. violacea: Site B

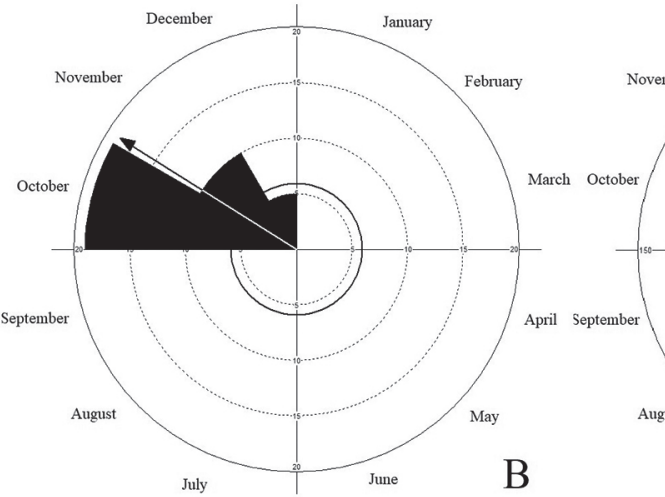

Eg. cordata: Site D2

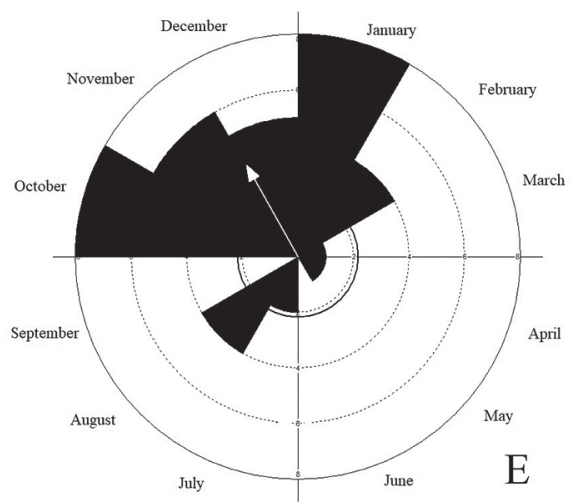

El. nigrita: Site B

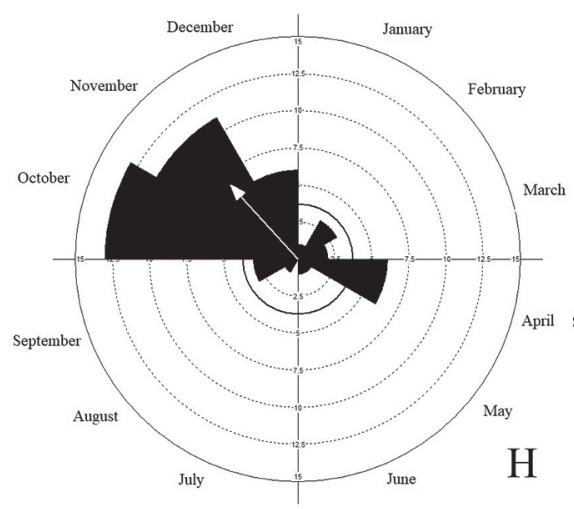

Ef. violacea: All Sites

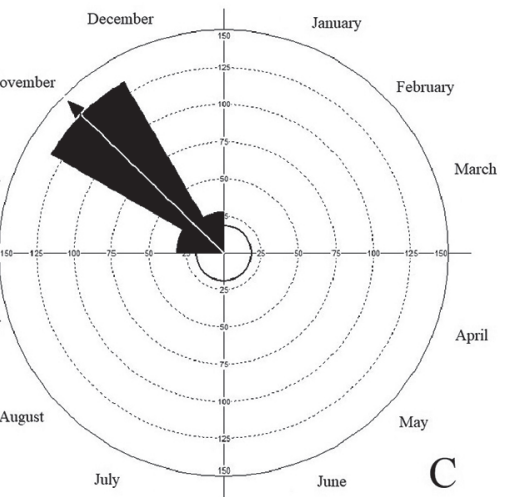

Eg. cordata: Site D

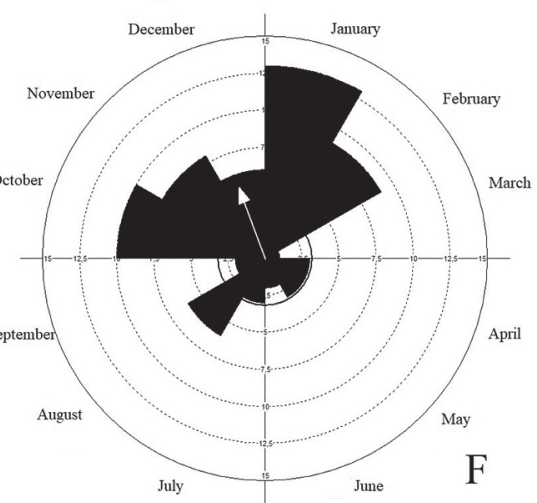

El. nigrita: All Sites

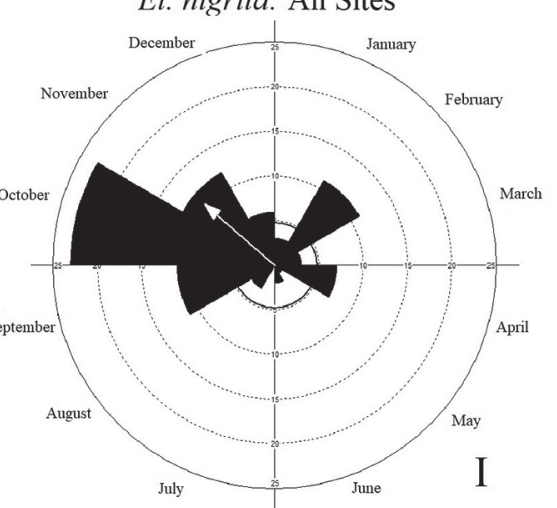

Figure 1. Orchid bee phenology in Seasonal Semideciduous Forest fragments, (A-C) Eufriesea violacea, (D-G) Euglossa cordata, (H-I) Eulaema nigrita. 

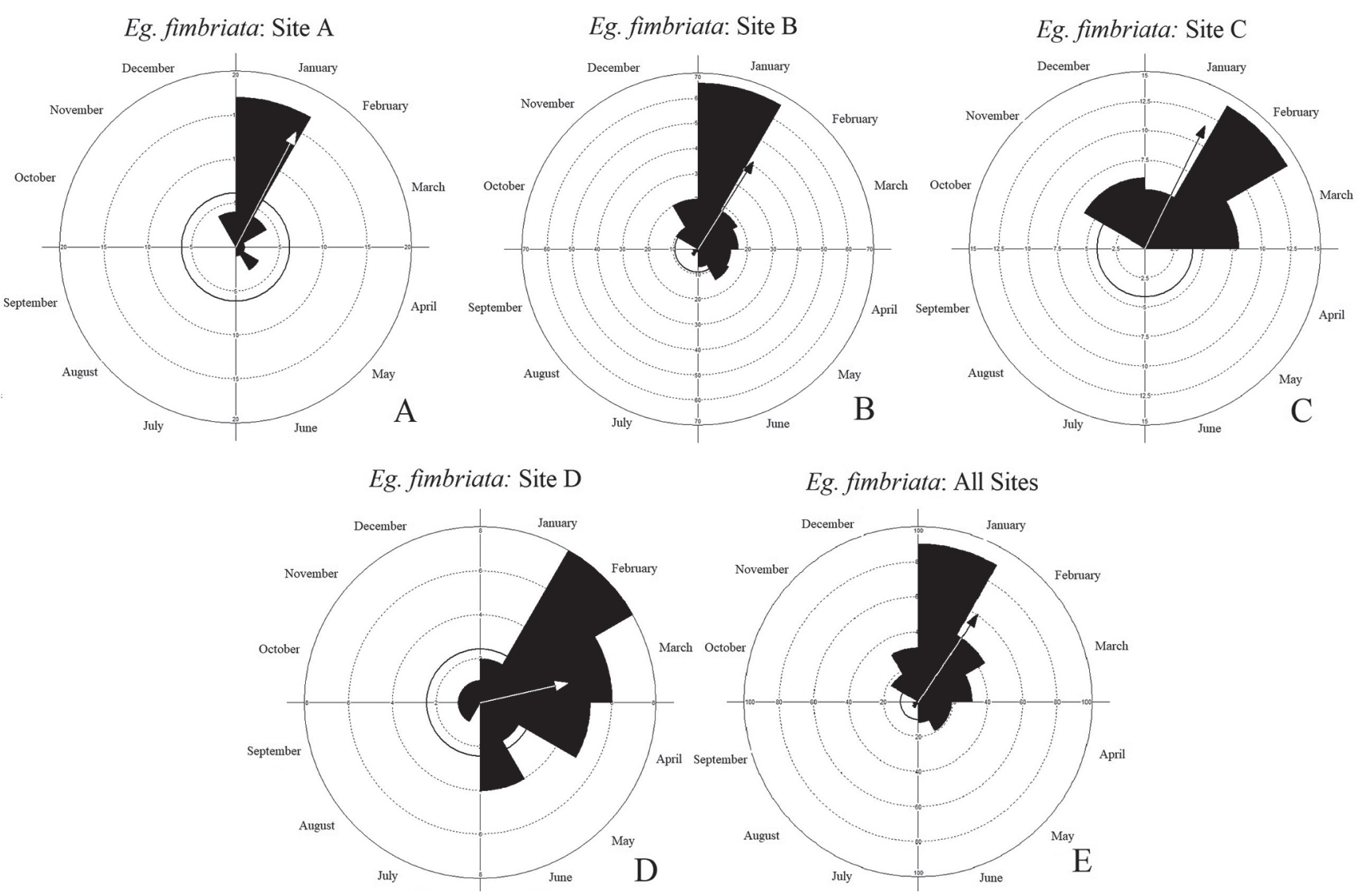

Figure 2. Orchid bee phenology in Seasonal Semideciduous Forest fragments, Euglossa fimbriata.

\section{DISCUSSION}

\section{Local faunas}

Regarding the newly sampled sites (C and D), the orchid bee richness was similar to results found in the other areas, as Gonçalves et al. (2014b) sampled seven species on Site A and Gonçalves et al. (2014a) sampled six species on Site B. According to Sydney \& Gonçalves (2015) the orchid bee fauna on Palotina region is composed by nine species, Eufriesea violacea, Eufriesea aff. auriceps, Euglossa annectans, Euglossa cordata, Euglossa fimbriata, Euglossa pleosticta, Euglossa aff. melanotricha, Eulaema nigrita and Exaerete smaragdina (Guérin, 1844). Richness and abundance of orchid bees in southern Atlantic forests are smaller than those from the northern Atlantic and Amazonian forests, what had already been shown by the negative correlation of orchid bees and the Neotropical latitudinal gradient of species richness (Sydney et al., 2010).

Regarding commonness, Eg. fimbriata was the most common species on sites $\mathrm{C}$ and $\mathrm{B}$ and Ef. violacea on Site A. Euglossa cordata was the most common species on site D1-2 and was also quite abundant on site B, but not on site $A$ (only one specimen collected). These results show that there is no clear pattern of dominance on the local assemblages, unlike what occurs in different areas of Atlantic forest where a single or a few common species dominate the local faunas (e.g., Aguiar \& Gaglianone, 2012; Oliveira et al., 2015). Besides the alleged existence of heterogeneity among samples of euglossine bees taken from nearby sites (Armbruster, 1993), this study was carried out towards the range limits of most species, where the populations are regarded to be highly fragmented (reviewed in Gaston, 2009). This could help to explain the dominance of different species in the four nearby sites.

\section{Patterns of seasonality}

Our data suggest a seasonal pattern in the variation of abundance of males of orchid bees in fragments of western Paraná, and such pattern was found in all the analyzed spatial and temporal contexts. Results also support the well-known suggestion that bee activity in tropical areas is not strictly seasonal throughout the year as in temperate regions (Sakagami et al., 1967), and specific dynamics of species resemble very much the results found for orchid bees in a region with marked rainy and drier season (Sofia et al., 2004; Knoll, 2016). Euglossine bees are regarded to have one of the most stable populations among insects (Roubik \& Ackerman, 1987), and when the entire data set is considered, it is relevant to point out that samplings where carried out over four years (even with an interruption between 08/2013 and $02 / 2014$ ). So, it is possible to consider that a general overview of phenological patterns can be made.

In general, euglossine activity was concentrated in the hot and rainy season, as observed in other areas covered by SSF (Rebêlo \& Garófalo, 1991, 1997; Sofia \& 
Suzuki, 2004; Sofia et al., 2004; Castro et al., 2013; Knoll, 2016), and species presented a phenological pattern similar to that of sites elsewhere in the Atlantic domain (e.g., Rocha-Filho \& Garófalo, 2014). As expected, only Ef. violacea showed a strong seasonality (defined here by $R$ values near one), being active only between October and December. It is interesting to contextualize this seasonal pattern within the known distribution of this species, as in southeastern Brazil, populations of Ef. violacea remain active longer, for about five months (Peruquetti \& Campos, 1997; Uehara-Prado \& Garófalo, 2006), while in latitudes more similar to this study (Schrottky, 1907) and even further south (Wittmann et al., 1988; Essinger, 2005), the three months of activity remain. However, some variation on a finer scale may also be operating, as in Paraguay, for instance, Schrottky (1907) noticed activity of this species from December to March, while in southern Santa Catarina the species flies from November to January (Essinger, 2005).

In the case of the patterns found for the other three species, it is important to consider both seasonal peaks in abundance and the period of year where they remain active. The results for Eulaema nigrita can be compared more specifically with SSF areas, as this species is common in distinct sites of this formation. With respect to phenology, the pattern found is the same, as the species presents a long period of activity during the year (Rebêlo \& Garófalo, 1991, 1997; Sofia et al., 2004; Castro et al., 2013; Knoll, 2016) but with decrease in activity in the coldest/ dry period of the year (Rebêlo \& Garófalo, 1997; Castro et al., 2013; Knoll, 2016). Moreover, a significantly seasonal pattern, with the highest abundance concentrated in early-middle summer was also registered by Castro et al. (2013) and Knoll (2016). Interestingly, however, the species remains active during the entire year in areas with seasonal climates in lower latitudes (e.g., Andrade-Silva et al., 2012, but see Rocha-Filho \& Garófalo, 2014).

Euglossa cordata occurs during the entire year, as observed in distinct areas along its distribution (e.g., Roubik \& Ackerman 1987; Aguiar \& Gaglianone, 2008; RochaFilho \& Garófalo, 2014), including areas with distinct climate seasonality, as Caatinga (Andrade-Silva et al., 2012). But a seasonal peak on abundance distribution was not stated by Castro et al. (2013) or Knoll (2016) in areas of SSF-Cerrado transition in southeastern Brazil. The pattern found here resembles the results found by RochaFilho \& Garófalo (2014) in coastal areas of Atlantic forest, as the species remained active during the year but with a significant concentration in the wet season.

When comparing the results of Euglossa fimbriata with those from other areas of SSF, the pattern found in the region of Palotina is somewhat different. This species is active throughout the year without evident seasonal variations in abundance in SSF areas in southeastern (Rebêlo \& Garófalo, 1997; Castro et al., 2013; Knoll, 2016) and southern Brazil (Sofia et al., 2004), not showing the marked seasonality in abundance that we present here.

Few studies have been performed to determine if physical factors such as temperature, radiation, humidity, photoperiod, or some combination of meteorological events trigger cessation of diapause and emergence of adult tropical bees (Roubik, 1989). Still, it is important to note that the environment influences the species phenology at the present time as well as it shapes the phenology during the evolutionary time (Visser et al., 2010). Three main factors are expected to drive the pattern we found, (i) life cycle and nesting behavior of species (e.g., Knoll, 2016), (ii) synchrony with resource availability (e.g., Ackerman, 1983; Roubik \& Ackerman, 1987), and (iii) seasonality in the climate (e.g., Silva \& Rebêlo, 2002). Factors operating on a local scale (Silva \& Rebêlo, 2002) also explain some variations on seasonal patterns observed, as the variation on Ef. violacea phenology.

Information on the life cycle and nesting behavior is paramount in understanding the seasonality of bees' abundance (Roubik \& Ackerman, 1987; Knoll, 2016). Nest re-use and reactivation may permit the species to be active during most time as several generations may be produced in the same location, and questions related to finding a suitable and protected nesting site, and nesting materials are strongly diminished (Roubik \& Ackerman, 1987). Both Eulaema nigrita and Euglossa cordata are known to present this behavior (Zucchi et al., 1969; Garófalo, 1985; Pereira-Martins, 1991; Santos \& Garófalo 1994; Augusto \& Garófalo, 2011; Freiria et al., 2017). Social cohesion in multifemale nests of Eg. cordata could also lead to long-lived colonies through successive reactivation processes (Augusto \& Garófalo, 2011), what could certainly increase the temporal stability of this species in highly seasonal habitats, as these colonies are able to produce males during the entire year.

But how to explain a period of activity so restrict for Euglossa fimbriata, a species that also presents nest reactivation processes, besides semi-social and eusocial organization (Augusto \& Garófalo, 2009)? Two main characteristics distinguish Eg. fimbriata from both El. nigrita and Eg. cordata in the present context. Firstly, this is the southernmost record of Eg. fimbriata and populations at range limits are subject to the inevitably rather unidirectional flow of immigrants and the steepness of any relevant environmental gradient (Gaston, 2009). Secondly, the species is less generalist regarding scents (e.g., Nemésio, 2009), what could make E. fimbriata more subject to temporal restriction of resources during the year. The pattern of activity of E. fimbriata may suggest this species is univoltine in the region besides undergoing diapause as prepupae. In higher latitudes, there is direct evidence for more than a single generation per year, coming from the study of nests (Augusto \& Garófalo, 2009) and by the collection of the species all year long (Rebêlo \& Garófalo, 1997). This plasticity in life history may be expected, as univoltine and multivoltine species are found in the same genus, regional differences appear in single species (Roubik, 1989) and bees may diapause as prepupae in periods of unfavorable nesting and foraging conditions (Roubik \& Michener, 1980).

Regarding resource availability, despite the obvious relation of females to flowers, in orchid bees this subject becomes even more important when considering that males depends on the access to aromatic compounds, 
mostly found in floral resources (e.g., Dressler, 1982). So, it is expected fluctuations in species abundance to be directly associated to the resource supply that follows the phenology of plants (e.g., Rocha-Filho \& Garófalo, 2014) and, in SSF areas, there is a significant seasonal pattern in plant phenology, with peak flowering during the rainy season (Mikich \& Silva, 2001; Marchioretto et al., 2007), which overlaps with the observed period of greater activity of species. Seasonality in climate and the consequent seasonality in plant phenology may also affect the dynamics of orchid bees via the turnover of the aromatic compounds provided year-round by the plants, and changes in the preferences for aromatic compounds by the species may also appear as a response to this scenario (Abrahamczyk et al., 2012).

Regarding climate, as the egg-to-adult period is influenced by temperature (Garófalo et al., 1993), it is expected the patterns of development to be particular in each region. The plasticity of individuals' time of development is regarded as an important response of euglossine bees to environmental fluctuation, with the production of several generations of short development in favorable contexts and delaying hatching, with increasing time as pupae, during unfavorable circumstances (Knoll, 2016). It is even possible to expect variation in the social organization itself, as sociality is dependent on local conditions and a single species may be either social or solitary (Schürch et al., 2016).

Climate change is expected to affect the timing of seasonal life history events of organisms (Parmesan, 2006), with potential risks for insects directly and for plant-pollinator interactions (e.g., Forrest, 2015). Empirical evidence exists for directional selection for earlier emergence of bees in the context of climate change, and rapid climate-driven shifts in the fitness could result in an increased risk of population extinction, particularly in scenarios where climate change occurs faster than phenological adaptation (Farzan \& Yang, 2018). The patterns we found should be considered in the context of climate changes in the region. In a comprehensive study on the behavior of climatic variables from 1973 to 2010 in the region of Palotina, a tendency of increasing amplitude and maximum temperature, besides the increased frequency of droughts and frosts, was observed (Pedron et al., 2013). So, we can postulate an important impact of climate change in local euglossine assemblage due to the small populations and marked seasonality.

\section{ACKNOWLEDGEMENTS}

We are grateful for the collection permits and licenses granted by the Instituto Ambiental do Paraná (permit number 328/11), Instituto Chico Mendes de Conservação da Biodiversidade (license number 12195-1), and Ivan Riedi for permission to access the studied area. CMA was supported by PROEC and VOB by CNPq undergraduate scholarship. Author contributions: RBG designed the study, CMA and VOB collected the data, CMA and RBG made the analyses, LRRF wrote the manuscript, and all authors revised the final version.

\section{REFERENCES}

Abrahamczyk, S.; Gottleuber, P. \& Kessler, M. 2012. Seasonal changes in odour preferences by male euglossine bees (Hymenoptera: Apidae) and their ecological implications. Apidologie, 43: 212-217.

Ackerman, J.D. 1983. Diversity and seasonality of male euglossine bees (Hymenoptera: Apidae) in central Panamá. Ecology, 64: 274-283.

Aguiar, W.M. \& Gaglianone, M.C. 2008. Comunidade de abelhas Euglossina (Hymenoptera: Apidae) em remanescentes de mata estacional semidecidual sobre tabuleiro no estado do Rio de Janeiro. Neotropical Entomology, 37: 118-125.

Aguiar, W.M. \& Gaglianone, M.C. 2012. Euglossine bee communities in small forest fragments of the Atlantic Forest, Rio de Janeiro state, southeastern Brazil (Hymenoptera, Apidae). Revista Brasileira de Entomologia, 56: 210-219.

Andrade-Silva, A.C.R.; Nemésio, A.; de Oliveira F.F. \& Nascimento, F.S. 2012. Spatial-Temporal Variation in Orchid Bee Communities (Hymenoptera: Apidae) in Remnants of Arboreal Caatinga in the Chapada Diamantina Region, State of Bahia, Brazil. Neotropical Entomology, 41: 296-305.

Armbruster, W.S. 1993. Within-habitat heterogeneity in baiting samples of male euglossine bees: possible causes and implications. Biotropica, 25: 122-128.

Augusto, S.C. \& Garófalo, C.A. 2009. Bionomics and sociological aspects of Euglossa fimbriata (Apidae, Euglossini). Genetics and Molecular Research, 8: 525-538.

Augusto, S.C. \& Garófalo, C.A. 2011. Task allocation and interactions among females in Euglossa carolina nests (Hymenoptera, Apidae, Euglossini). Apidologie, 42: 162-173.

Batschelet, E. 1981. Circular statistics in biology. London, Academic Press.

Campos, L.A.O.; Silveira, F.A.; Oliveira, M.L.; Abrantes, C.V.M.; Morato, E.F. \& Melo, G.A.R. 1989. Utilização de armadilhas para a captura de machos de Euglossini (Hymenoptera, Apoidea). Revista Brasileira de Zoologia, 6: 621-626.

Castro, M.M.N.; Garófalo, C.A.; Serrano, J.C. \& Silva, C.I. 2013. Temporal variation in the abundance of orchid bees (Hymenoptera: Apidae) in a Neotropical hygrophilous forest. Sociobiology, 60: 405-412.

Danks, H.V. 2007. The elements of seasonal adaptations in insects. The Canadian Entomologist, 139: 1-44.

Dodson, C.H.; Dressler, R.L.; Hills, H.G.; Adams, R.M. \& Williams, N.H. 1969. Biologically active compounds in orchid fragrances. Science, 164: 1243-1249.

Dressler, R.L. 1982. Biology of the orchid bees (Euglossini). Annual Review of Ecology and Systematics, 13: 373-394.

Essinger, L.N. 2005. Euglossini (Apidae, Hymenoptera) no sul de Santa Catarina. MSc. Dissertation. Criciúma, UNESC. 63p.

Faria, L.R.R. \& Melo, G.A.R. 2007. Species of Euglossa (Glossura) in the Brazilian Atlantic forest, with taxonomic notes on Euglossa stellfeldi Moure (Hymenoptera, Apidae, Euglossina). Revista Brasileira de Entomologia, 51:275-284.

Farzan, S. \& Yang, L.H. 2018. Experimental shift in phenology affects fitness, foraging, and parasitism in a native solitary bee. Ecology, 99(10): 2187-2195. DOI

Forrest, J.R.K. 2015. Plant - pollinator interactions and phenological change: what can we learn about climate impacts from experiments and observations? Oikos, 124: 4-13.

Freiria, G.A.; Garófalo, C.A. \& Del Lama, M.A. 2017. The primitively social behavior of Euglossa cordata (Hymenoptera, Apidae, Euglossini): a view from the perspective of kin selection theory and models of reproductive skew. Apidologie, 48: 523-532.

Garófalo, C.A. 1985. Social structure of Euglossa cordata nests (Hymenoptera: Apidae: Euglossini). Entomologia Generalis, 11: 77-83. 
Garófalo, C.A.; Camillo, E. \& Serrano, J.C. 1993. Utilization of trap nests by Euglossini species (Hymenoptera: Apidae). Revista Brasileira de Biologia, 53: 177-187.

Gaston, K.J. 2009. Geographic range limits: achieving synthesis. Proceedings of the Royal Society B, 276: 1395-1406.

Gonçalves, R.B.; Sydney, N.V.; Oliveira, P.S. \& Artmann, N.0. 2014a. Bee and wasp responses to a fragmented landscape in southern Brazil. Journal of Insect Conservation, 18: 1193-1201.

Gonçalves, R.B.; Scherer, V.L. \& Oliveira, P.S. 2014b. The orchid bees (Hymenoptera, Apidae, Euglossina) in a forest fragment from western Paraná state, Brazil. Papéis Avulsos de Zoologia, 54: 63-68.

Instituto Brasileiro de Geografia e Estatística (IBGE). 2018. Brasil em síntese. Available at: https://cidades.ibge.gov.br. Accessed in: 17/01/2019.

Janzen, D.H.; Devries, P.J.; Heggins, M.L. \& Kimsey, L.S. 1982. Seasonal and site variation in Costa Rican euglossine bees at chemical baits in lowland deciduous and evergreen forests. Ecology, 63: 66-74.

Kimsey, L.S. 1982. Systematics of bees of the genus Eufriesea. University of California Publications in Entomology, 95: 1-125.

Knoll, F.R. 2016. Variation in the abundance of Neotropical bees in an unpredictable seasonal environment. Neotropical Entomology, 45: 129-138.

Kovach, W.L. 2011. Oriana: Circular Statistics for Windows (version 4.0). Pentraeth, Kovach Computer Services.

Marchioretto, M.A.; Mauhs, J. \& Budke, J.C. 2007. Fenologia de espécies arbóreas zoocóricas em uma floresta psamófila no sul do Brasil. Acta Botanica Brasilica, 21: 193-201.

Marinoni, R.C. \& Ganho, N.G. 2003. Sazonalidade de Nyssodrysina lignaria (Bates) (Coleoptera, Cerambycidae, Lamiinae), no estado do Paraná, Brasil. Revista Brasileira de Zoologia, 20: 141-152.

Marques, M.C.M.; Roper, J.J. \& Salvalaggio, A.P.B. 2004. Phenological patterns among plant life forms in a subtropical forest in Southern Brazil. Plant Ecology, 173: 203-213.

Mateus, S.; Andrade, A.C.R. \& Garófalo, C.A. 2015. Diversity and temporal variation in the orchid bee community (Hymenoptera: Apidae) of a remnant of a Neotropical seasonal semi-deciduous forest. Sociobiology, 62(4): 571-577.

Mikich, S.B. \& Silva, S.M. 2001. Composição florística e fenologia das espécies zoocóricas de remanescentes de Floresta Estacional Semidecidual no centro-oeste do Paraná, Brasil. Acta Botanica Brasílica, 15: 89-113.

Morellato, L.P.C.; Talora, D.C.; Takahasi, A.; Bencke, C.C.; Romera, E.C. \& Zipparro, V.B. 2000. Phenology of Atlantic rain forest trees: a comparative study. Biotropica, 32: 811-823.

Moure, J.S.; Melo, G.A.R. \& Faria Jr., L.R.R. 2007. Euglossini Latreille, 1802. In: Moure, J.S.; Urban, D. \& Melo, G.A.R. (Eds.). Catalogue of Bees (Hymenoptera, Apoidea) in the Neotropical Region. Curitiba, Sociedade Brasileira de Entomologia. p. 214-255.

Nemésio, A. 2009. Orchid bees (Hymenoptera: Apidae) of the Brazilian Atlantic Forest. Zootaxa, 2041: 1-242.

Nemésio, A. \& Silveira, F.A. 2006. Edge effects on the orchid-bee fauna (Hymenoptera: Apidae) at a large remnant of Atlantic Forest in southeastern Brazil. Neotropical Entomology, 35: 313-323.

Oliveira, R.; Pinto, C.E. \& Schlindwein, C. 2015. Two common species dominate the species-rich Euglossine bee fauna of an Atlantic Rainforest remnant in Pernambuco, Brazil. Brazilian Journal of Biology, 75: S1-S8.

Parmesan, C. 2006. Ecological and evolutionary responses to recent climate change. Annual Review of Ecology, Evolution, and Systematics, 37: 637-669.

Pedron, I.T.; Mariani, K.L.; Farias, J.L.R. \& Rossetto, A. 2013. Comportamento do clima de Palotina, PR de 1973 a 2010. Scientia Agraria Paranaensis, 12: 411-419.
Pereira-Martins, S.R. 1991. Biologia de Eulaema nigrita. 2. Atividades nidais. Papéis Avulsos de Zoologia, 37: 237-243.

Peruquetti, R.C. \& Campos, L.A.O. 1997. Aspectos da biologia de Euplusia violacea (Blanchard) (Hymenoptera, Apidae, Euglossini). Revista Brasileira de Zoologia, 14: 91-97.

Peruquetti, R.C.; Campos, L.A.0.; Coelho, C.D.P.; Abrantes, C.V.M. \& Lisboa, L.C.0. 1999. Abelhas Euglossini (Apidae) de áreas de Mata Atlântica: abundância, riqueza e aspectos biológicos. Revista Brasileira de Zoologia, 16: 101-118.

Powell, J.A. \& Logan, J.A. 2005. Insect seasonality: circle map analysis of temperature-driven life cycles. Theoretical Population Biology, 67: 161-179.

Ramírez, S.R.; Roubik, D.W.; Skov, C. \& Pierce, N.E. 2010. Phylogeny, diversification patterns and historical biogeography of euglossine orchid bees (Hymenoptera: Apidae). Biological Journal of the Linnean Society, 100:552-572.

Rebêlo, J.M.M. \& Garófalo, C.A. 1991. Diversidade e sazonalidade de machos de Euglossini (Hymenoptera, Apidae) e preferência por iscas odores em um fragmento de floresta no sudeste do Brasil. Revista Brasileira de Biologia, 51: 787-799.

Rebêlo, J.M.M. \& Garófalo, C.A. 1997. Comunidades de machos de Euglossinae (Hymenoptera, Apidae) em matas semidecíduas do nordeste do estado de São Paulo. Anais da Sociedade Entomológica do Brasil, 26: 243-256.

Rebêlo, J.M.M. \& Moure, J.S. 1996. As espécies de Euglossa Latreille do nordeste de São Paulo (Apidae, Euglossinae). Revista Brasileira de Zoologia, 12: 445-466.

Richards, L.A. \& Windsor, D.M. 2007. Seasonal variation of arthropod abundance in gaps and the understorey of a lowland moist forest in Panama. Journal of Tropical Ecology, 23: 169-176.

Riedel, R.; Marinoni, R.C. \& Martins-Opolis, N. 2008. Spatio-temporal trends of insect communities in southern Brazil. Journal of Entomology, 5: 369-380.

Rocha-Filho, L.C. \& Garófalo, C.A. 2014. Phenological patterns and preferences for aromatic compounds by male euglossine bees (Hymenoptera, Apidae) in two coastal ecosystems of the Brazilian Atlantic forest. Neotropical Entomology, 43: 9-20.

Roubik, D.W. 1989. Ecology and natural history of tropical bees. Cambridge, Cambridge University Press, 528p.

Roubik, D.W. \& Ackerman, J.D. 1987. Long-term ecology of euglossine orchidbees (Apidae: Euglossini) in Panama. Oecologia, 73: 321-333.

Roubik, D.W. \& Hanson, P.E. 2004. Orchid bees of tropical America: biology and field guide. San Jose, INBI0. 370p.

Roubik, D.W. \& Michener, C.D. 1980. The seasonal cycle and nests of Epicharis zonata, a bee whose cells are below the wet-season water table (Hymenoptera, Anthophoridae). Biotropica, 12: 56-60.

Sakagami, S.F.; Laroca, S. \& Moure, J.S. 1967. Wild bees biocenotics in São José dos Pinhais (PR), South Brazil - preliminary report. Journal of the Faculty of Sciences of the Hokkaido University, Series 6, Zoology, 19: 253-91.

Santos, M.L. \& Garófalo, C.A. 1994. Nesting biology and nest re-use of Eulaema nigrita (Hymenoptera: Apidae, Euglossini). Insectes Sociaux, 41: 99-110.

Schrottky, C. 1907. Contribución al conocimiento de los himenópteros del Paraguay. Anales de Ciêntificos Paraguayos, 7: 1-78.

Schürch, R.; Accleton, C. \& Field, J. 2016. Consequences of a warming climate for social organisation in sweat bees. Behavioral Ecology and Sociobiology, 70: 1131-1139.

Silva, F.S. \& Rebêlo, J.M.M. 2002. Population dynamics of euglossine bees (Hymenoptera, Apidae) in an early second-growth forest of Cajual Island, in the state of Maranhão, Brazil. Brazilian Journal of Biology, 62: 15-23.

Soares, A.A.; Campos, L.A.0.; Vieira; M.F. \& Melo, G.A.R. 1989. Relações entre Euglossa (Euglossella) mandibularis Friese, 1899 (Hymenoptera, Apidae, 
Euglossini) e Cyphomandra calycina (Solanaceae). Ciência e Cultura, 41(9): 903-905.

Sobral-Souza, T.; Francini, R.B.; Guimarães, M. \& Benson, W.W. 2015. Shortdynamics reveals seasonality in a subtropical Heliconius butterfly. Journal of Insects, 2015(ID761058): 1-5. Available in: https://www.hindawi. com/journals/insects/2015/761058.

Sofia, S.H. \& Suzuki, K.M. 2004. Comunidades de machos de abelhas Euglossina (Hymenoptera: Apidae) em fragmentos florestais no sul do Brasil. Neotropical Entomology, 33: 693-702.

Sofia, S.H.; Santos, A.M. \& Silva, C.R.M. 2004. Euglossine bees (Hymenoptera, Apidae) in a remnant of Atlantic Forest in Paraná state, Brazil. Iheringia, Série Zoologia, 94: 217-222.

Sydney, N.V. \& Gonçalves, R.B. 2015. Is the capture success of orchid bees (Hymenoptera, Apoidea) influenced by diferent baited trap designs? A case study from southern Brazil. Revista Brasileira de Entomologia, 59: 34-38.

Sydney, N.V.; Gonçalves, R.B. \& Faria, L.R.R. 2010. Padrões espaciais na distribuição de abelhas Euglossina (Hymenoptera, Apidae) da região Neotropical. Papéis Avulsos de Zoologia, 50: 667-679.

Tauber, M.J.; Tauber, C.A. \& Masaki, S. 1986. Seasonal adaptations of insects. New York, Oxford University Press. 411p.

Turchin, P.; Taylor, A.D. \& Reeve, J.D. 1999. Dynamical role of predators in population cycles of a forest insect: an experimental test. Science, 285 : 1068-1071.
Uehara-Prado, M. \& Garófalo, C.A. 2006. Small-scale elevational variation in the abundance of Eufriesea violacea (Blanchard) (Hymenoptera: Apidae). Neotropical Entomology, 35: 446-451.

Veloso, H.P.; Rangel, A.L.R. \& Lima, J.C.A. 1991. Classificação da vegetação brasileira, adaptada a um sistema universal. Rio de Janeiro, IBGE-DERMA.

Visser, M.E.; Caro, S.P.; van Oers, K.; Schaper, S.V. \& Helm, B. 2010. Phenology, seasonal timing and circannual rhythms: towards a unified framework. Philosophical Transactions of the Royal Society B: Biological Sciences, 365: 3113-3127. DOI

Wittmann, D.; Radtke, R.; Hoffmann, M. \& Blochstein, B. 1989. Seasonality and seasonal changes in preferences for scent baits in Euplusia violacea in Rio Grande do Sul, Brazil (Hymenoptera, Apidae, Euglossini). Entomologia Generalis, 14: 217-221.

Wolda, H. 1978. Seasonal fluctuations in rainfall, food and abundance of tropical insects. Journal of Animal Ecology, 47: 369-381.

Wolda, H. 1980. Seasonality of tropical insects. I. Leafhoppers (Homoptera) in Las Cumbres, Panama. Journal of Animal Ecology, 49: 277-290.

Wolda, H. 1988. Insect seasonality: why? Annual Review of Ecology and Systematics, 19: 1-18.

Zar, J.H. 1996. Biostatistical analysis. 3. ed. New Jersey, Prentice-Hall International Editions.

Zucchi, R.; Sakagami, F. \& Camargo, J.M.F. 1969. Biological observations on a Neotropical parasocial bee, Eulaema nigrita, with a review of the biology of Euglossinae: a comparative study. Journal of the Faculty of Sciences of the Hokkaido University, Series 6, Zoology, 17: 271-380. 
SUPPLEMENTARY MATERIAL

Orchid bee phenology in Seasonal Semideciduous Forest fragments, raw data.

\begin{tabular}{|c|c|c|c|c|c|c|}
\hline Site A & Eufriesea violacea & Euglossa annectans & Euglossa cordata & Euglossa fimbriata & Euglossa pleosticta & Eulaema nigrita \\
\hline $05 / X / 2011$ & 0 & 1 & 0 & 0 & 0 & 0 \\
\hline 07/XI/2011 & 117 & 0 & 1 & 0 & 0 & 0 \\
\hline 14/XII/2011 & 23 & 0 & 0 & 4 & 0 & 0 \\
\hline $16 / 1 / 2012$ & 0 & 0 & 0 & 17 & 0 & 2 \\
\hline $23 / 11 / 2012$ & 0 & 0 & 0 & 4 & 0 & 2 \\
\hline $29 / 111 / 2012$ & 0 & 0 & 0 & 1 & 1 & 0 \\
\hline 05/IV/2012 & 0 & 1 & 0 & 1 & 0 & 0 \\
\hline 29/V/2012 & 0 & 3 & 0 & 3 & 0 & 0 \\
\hline 14/VI/2012 & 0 & 3 & 0 & 1 & 0 & 0 \\
\hline $01 / \mathrm{VII} / 2012$ & 0 & 0 & 0 & 0 & 0 & 0 \\
\hline $01 / \mathrm{VIII} / 2012$ & 0 & 0 & 0 & 0 & 0 & 0 \\
\hline 01/IX/2012 & 0 & 0 & 0 & 0 & 0 & 0 \\
\hline
\end{tabular}

$\begin{array}{llllll}\text { Site B } & \text { Eufriesea violacea Euglossa annectans } & \text { Euglossa cordata } & \text { Euglossa fimbriata } & \text { Euglossa pleosticta }\end{array}$

$15 / \mathrm{VIII} / 2012$

$04 / I X / 2012$

$08 / \mathrm{X} / 2012$

$16 / X I / 2012$

10/XII/2012

$16 / / / 2013$

$17 / I I / 2013$

23/III/2013

$10 /$ IV/2013

$01 / \mathrm{V} / 2013$

$01 / \mathrm{VI} / 2013$

06/VII/2013

\begin{tabular}{lccc}
\hline sa cordata & Euglossa fimbriata & Euglossa pleosticta & Eulaema nigrita \\
\hline 1 & 3 & 0 & 1 \\
7 & 2 & 0 & 3 \\
4 & 0 & 1 & 13 \\
2 & 10 & 0 & 11 \\
2 & 20 & 0 & 6 \\
6 & 66 & 0 & 1 \\
9 & 18 & 0 & 3 \\
2 & 16 & 0 & 2 \\
2 & 13 & 1 & 6 \\
2 & 14 & 0 & 1 \\
2 & 7 & 0 & 1 \\
0 & 1 & 0 & 0
\end{tabular}

$\begin{array}{ccccccc}\text { Site C } & \text { Eufriesea violacea } & \text { Euglossa annectans } & \text { Euglossa cordata } & \text { Euglossa fimbriata } & \text { Euglossa pleosticta } & \text { Eulaema nigrita }\end{array}$

$04 / 111 / 2014$

$01 / \mathrm{IV} / 2014$

$01 / \mathrm{V} / 2014$

$19 / \mathrm{VI} / 2014$

$01 / \mathrm{VII} / 2014$

01/VIII/2014

$30 / I X / 2014$

$29 / X / 2014$

26/XI/2014

29/XII/2014

$14 / / / 2015$

03/II/2015

\begin{tabular}{cccc} 
sa cordata & Euglossa fimbriata & Euglossa pleosticta & Eulaema nigrita \\
\hline 1 & 8 & 1 & 0 \\
0 & 0 & 0 & 0 \\
0 & 0 & 0 & 0 \\
0 & 0 & 0 & 1 \\
0 & 0 & 0 & 0 \\
0 & 0 & 0 & 0 \\
1 & 0 & 0 & 2 \\
1 & 0 & 0 & 1 \\
4 & 6 & 0 & 1 \\
1 & 6 & 1 & 0 \\
3 & 5 & 0 & 0 \\
3 & 14 & 0 & 1 \\
\hline
\end{tabular}

Site D1

25/VI/2014

22/VII/2014

07/VIII/2014

18/IX/2014

$16 / X / 2014$

$14 / \mathrm{XI} / 2014$

$08 / / / 2015$

$03 / 11 / 2015$

20/III/2015

$15 / I V / 2015$

13/V/2015

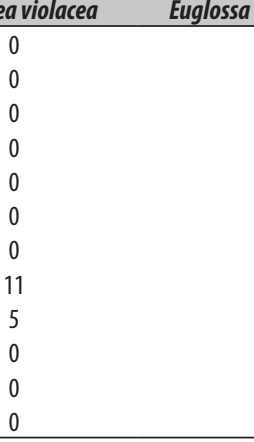

1
0
0
0
0
0
1
1
4
1
3
3

Euglossa pleosticta

Eulaema nigrita

Site D2

12/VIII/2015

$09 / I X / 2015$

$07 / X / 2015$

$05 / \mathrm{XI} / 2015$

$08 / \mathrm{XII} / 2015$

$07 / / / 2016$

$09 / 11 / 2016$

$16 / 111 / 2016$

$11 /$ IV/2016

23/V/2016

$06 / \mathrm{VI} / 2016$

$04 / \mathrm{VII} / 2016$

\begin{tabular}{cr} 
Eufriesea violacea & Euglossa \\
\hline 0 & 0 \\
0 & 0 \\
0 & 1 \\
0 & 1 \\
1 & 0 \\
0 & 0 \\
0 & 0 \\
0 & 0 \\
0 & 0 \\
0 & 0 \\
0 & 0
\end{tabular}

\begin{tabular}{ccc}
\hline annectans & Euglossa cordata & Eugloss \\
0 & 2 \\
0 & 1 \\
1 & 2 \\
1 & 2 \\
0 & 2 \\
0 & 3 \\
0 & 5 \\
0 & 5 \\
0 & 0 \\
0 & 2 \\
0 & 2
\end{tabular}

0
0
0
0
0
1
1
7
4
3
1

$\begin{array}{ll}0 & 0 \\ 0 & 0 \\ 0 & 0 \\ 0 & 5 \\ 0 & 8 \\ 0 & 0 \\ 0 & 0 \\ 0 & 4 \\ 0 & 0 \\ 0 & 0 \\ 0 & 0\end{array}$

\begin{tabular}{cccccc} 
Eufriesea violacea & Euglossa annectans & Euglossa cordata & Euglossa fimbriata & Euglossa pleosticta & Eulaema nigrita \\
\hline 0 & 0 & 4 & 1 & 0 & 0 \\
0 & 0 & 0 & 1 & 0 & 1 \\
1 & 0 & 8 & 1 & 1 & 1 \\
1 & 0 & 6 & 1 & 1 & 0 \\
0 & 0 & 5 & 1 & 0 & 0 \\
0 & 0 & 8 & 1 & 0 & 1 \\
0 & 0 & 4 & 2 & 2 & 1 \\
0 & 0 & 1 & 1 & 0 & 1 \\
0 & 0 & 1 & 1 & 0 & 0 \\
0 & 0 & 1 & 4 & 0 & 0 \\
0
\end{tabular}

